\title{
Agronomic biofortification with zinc on yield, nutritional quality, nutrient uptake and economics of babycorn
}

\section{G. Tamil Amutham*}

Department of Agronomy, Agriculture College and Research Institute, Tamil Nadu Agricultural University, Coimbatore- 641003 (Tamil Nadu), India

\section{R. Karthikeyan}

Department of Agronomy, Agriculture College and Research Institute, Tamil Nadu Agricultural University, Coimbatore- 641003 (Tamil Nadu), India

\section{N. Thavaprakaash}

Department of Agronomy, Agriculture College and Research Institute, Tamil Nadu Agricultural University, Coimbatore- 641003 (Tamil Nadu), India

\section{Bharathi}

Department Soil Science and Agricultural Chemistry, Agriculture College and Research Institute, Tamil Nadu Agricultural University, Coimbatore- 641003 (Tamil Nadu), India

*Corresponding author. Email: tamilhasina95@gmail.com

\section{Article Info}

https://doi.org/10.31018/

jans.v13iSI.2804

Received: March 22, 2021

Revised: May 14, 2021

Accepted: June 3, 2021

\section{How to Cite}

Amutham, G. T. et al. (2021). Agronomic biofortification with zinc on yield, nutritional quality, nutrient uptake and economics of babycorn. Journal of Applied and Natural Science, 13 (SI), 80 - 85. https://doi.org/10.31018/jans.v13iSI.2804

\begin{abstract}
The aim of the present study was to investigate the effect of agronomic biofortification with zinc on yield, nutritional quality, nutrient uptake and economics of babycorn under irrigated condition. The observations on yield viz., green cob yield, babycorn yield and green fodder yield and quality parameters (crude protein, total soluble sugars, starch and $\mathrm{Zn}$ content) were recorded at harvest stage. The nutrient uptake was analysed at different growth stages and economic indices viz., the total cost of cultivation, gross return, net return and benefit cost ratio were worked out for various zinc fertilization treatments. Increased green cob yield and babycorn yield was recorded higher in soil application of zinc sulphate @ $37.5 \mathrm{~kg} \mathrm{ha}^{-1}$ along with a foliar spray of 1.0 $\%$ on 20 and 40 DAS. Quality parameters of babycorn viz., crude protein, total soluble sugars, starch and Zn content in corn were significantly increased with soil application of $\mathrm{ZnSO}_{4} @ 37.5 \mathrm{~kg} \mathrm{ha}^{-1}$ along with a foliar spray of $0.5 \%$ at 20 and 40 DAS that recorded higher values of these quality characters. Plant nutrient uptake of $\mathrm{N}, \mathrm{K}$ and $\mathrm{Zn}$ in babycorn was significantly increased with the application of $\mathrm{ZnSO}_{4} @ 37.5 \mathrm{~kg} \mathrm{ha}^{-1}$ in soil with foliar spray of $0.5 \%$ at 20 and 40 DAS. Higher net monetary returns and $\mathrm{B}$ : $\mathrm{C}$ ratio were obtained with application of $\mathrm{ZnSO}_{4} @ 37.5 \mathrm{~kg} \mathrm{ha}^{-1}$ in soil with foliar spray @ $0.5 \%$ on 20 and 40 DAS.
\end{abstract}

Keywords: Babycorn hybrid G-5414, Green cob yield, Zinc uptake, Zinc biofortification

\section{INTRODUCTION}

Maize (Zea mays L.) is popularly called as 'Queen of cereals' and 'miracle crop' because of its greater yield potential. A novelty of maize is cultivation predominantly for vegetable purpose as 'babycorn'. Babycorn is typically a maize ear produced from regular corn plants which are harvested earlier, particularly when the silks have the size of 1-3 cm (Thavaprakaash et al., 2005). Babycorn is the safest vegetable to eat directly as it is (Kawatra and Sehgal, 2007). It has a high nutritive value and its nutritional quality is superior to some of the high priced vegetables such as tomato, cucumber, cabbage and cauliflower (Yodpet, 1979).
Zinc $(\mathrm{Zn})$ is one of the foremost trace elements required in minimum concentrations for healthy growth and development of plants and humans. In plants, zinc plays a vital role in pollen formation, enzyme activation, healthy root structure, detoxification of free radicals, resistance to certain pathogens (Peck and Mcdonald, 2010). In human, $\mathrm{Zn}$ has an essential role in the regulation of the immune system, neuron sensory functions and reproductive organs (Hershfinkel et al., 2007).

In the world, nearly 50 percent (\%) of cereal have been growing in low Zn status soil (Graham and Welch, 2008). Zinc deficiency in plants affects the crop quality and causes $\mathrm{Zn}$ deficiency in human diet (Bagci et al., 2007). In Asia, about 2.50 billion people were suffered 
by zinc deficiencies between the age group of 0-5 years (Caballero, 2002).

Among the field crops, maize is highly susceptible to zinc and it's occupied the third rank in zinc demand after rice and wheat (Meena et al., 2013). The fundamental of agronomic zinc biofortification is keeping an adequate quantity of available zinc in the soil solution by soil application and in the leaf tissues by foliar spray, which maintains sufficient level of zinc in the plant by encouraging root uptake and transport to the sink (grains) during reproductive stage of crop.

Agronomic zinc biofortification in babycorn has a great scope in alleviating zinc related deficiencies in the crop as well as in human beings by consumption of $\mathrm{Zn}$ enriched babycorn. Based on this above information the present study was aimed to investigate the agronomic biofortification with zinc on yield, nutritional quality, nutrient uptake and economics of babycorn.

\section{MATERIALS AND METHODS}

The field experiment was conducted during the late Kharif season (September-November) of the year 2018 at Eastern Block farm, Department of Agronomy, Tamil Nadu Agricultural University, Coimbatore, Tamil Nadu. The farm is located in the Western Agro Climatic Zone of Tamil Nadu at $11^{\circ} \mathrm{N}$ latitude, $77^{\circ} \mathrm{E}$ longitude, and at an altitude of $426.7 \mathrm{~m}$ above MSL. During the cropping period, a total of $324.4 \mathrm{~mm}$ rainfall was received over 31 rainy days. Texture of the experimental site was sandy clay loam belonging to Irugur series and taxonomically known as Typic Ustropepts under USDA classification. Before start of the field experiment the soil nutrient status of the experimental field was slightly alkaline (8.24) with low soluble salts $\left(0.53 \mathrm{dS} \mathrm{m}^{-1}\right)$, low in available nitrogen, medium in available phosphorus, high in available potassium with low in $\mathrm{Zn}$ content.

The field experiment was laid out in randomized complete block design (RCBD) with nine treatments and three replications. The treatments comprised of $\mathrm{T}_{1}$ : No zinc (control), $\mathrm{T}_{2}: \mathrm{ZnSO}_{4} @ 25 \mathrm{~kg} \mathrm{ha}^{-1}$ as soil application, $\mathrm{T}_{3}: \mathrm{ZnSO}_{4} @ 37.5 \mathrm{~kg} \mathrm{ha}{ }^{-1}$ as soil application, $\mathrm{T}_{4}$ : Foliar spray of $\mathrm{ZnSO}_{4} @ 0.5 \%$ on 20 and $40 \mathrm{DAS}, \mathrm{T}_{5}$ : Foliar spray of $\mathrm{ZnSO}_{4} @ 1.0 \%$ on 20 and 40 DAS, T $\mathrm{ZnSO}_{4} @ 25 \mathrm{~kg}$ ha ${ }^{-1}$ as soil application + foliar spray @ $0.5 \%$ on 20 and 40 DAS, $7: \mathrm{ZnSO}_{4} @ 25 \mathrm{~kg} \mathrm{ha}^{-1}$ as soil application + foliar spray @ $1.0 \%$ on 20 and 40 DAS, $\mathrm{T}_{8}: \mathrm{ZnSO}_{4} @ 37.5 \mathrm{~kg} \mathrm{ha}{ }^{-1}$ as soil application + foliar spray @ 0.5\% on 20 and 40 DAS, T9: ZnSO $@$ $37.5 \mathrm{~kg} \mathrm{ha}^{-1}$ as soil application + foliar spray @ 1.0\% on 20 and 40 DAS. Babycorn hybrid G-5414 was used for the experimentation with adopted plant spacing of 45 $\mathrm{cm} \times 25 \mathrm{~cm}$.

The blanket recommendation of fertilisers viz., nitrogen (150 kg ha ${ }^{-1}$ ), phosphorus (60 kg ha ${ }^{-1}$ ) and potassium (40 kg ha ${ }^{-1}$ ) were applied in the form of urea, single super phosphate and muriate of potash, respectively. $\mathrm{N}$ and $\mathrm{K}$ were applied in two equal splits i.e., one at the time of sowing and another at 25 days after sowing (DAS). The full dose of $P$ was applied as basal. As per the treatment schedule, the recommended quantity of zinc sulphate was applied as basal and foliar spray of zinc sulphate @ $0.5 \%$ and $1.0 \%$ was given at 20 and 40 DAS based on the treatments.

\section{Yield analysis:}

\section{Green cob yield}

The green cobs from the plants were harvested by five times and a sum of five pickings of fresh green cobs weight was taken and expressed as $\mathrm{kg} \mathrm{ha}^{-1}$.

\section{Babycorn yield}

The green cobs from the plants were harvested, the weight of fresh green cobs without husk (babycorns) was taken and expressed as $\mathrm{kg} \mathrm{ha}^{-1}$.

\section{Green fodder yield}

After the final harvest of green cobs, the left-over green plants were cut immediately to the ground level and the green fodder was weighed and expressed in $\mathrm{kg} \mathrm{ha}^{-1}$.

\section{Quality analysis:}

\section{Crude protein content}

Babycorn samples were taken at first picking from each net plot area and dried at $70^{\circ} \mathrm{C}$ in hot air oven. Those sample were used for the analysis of total $\mathrm{N}$ by MicroKjeldahl method (Humphries, 1956). The $\mathrm{N}$ content of the grain was multiplied with the factor 6.25 to get the crude protein and expressed in percentage (Dubetz and Wells, 1968).

\section{Total soluble sugars}

Total soluble sugars content were analysed in fresh corn at first picking by the method of Yemm and Willis (1954) and expressed in percentage.

\section{Starch content}

Starch content was estimated in fresh corn at first picking using Anthrone method by Hedge and Hofreiter (1962) and expressed as percentage.

\section{Zinc content in babycorn}

Zinc content was estimated in dried babycorn samples at first picking by Tri acid digestion method and using Atomic absorption spectrophotometer (Jackson, 1973) and expressed as ppm.

\section{Plant analysis}

The plant samples were collected at various growth stages (25 DAS, 45 DAS and at harvest) and kept for 
shade-dried followed by oven-dried. Then ground into a fine powder using Willey mill and it is used for chemical analysis of total $\mathrm{N}, \mathrm{P}, \mathrm{K}$ and $\mathrm{Zn}$.

The uptake of nutrients (NPK and $\mathrm{Zn}$ ) was worked out using the following formula.

Nutrient uptake $(\mathrm{kg} / \mathrm{ha})=$ Percentage of nutrient $\mathrm{x}$ Total dry matter production $(\mathrm{kg} / \mathrm{ha}) / 100$ Eq. 1

\section{Economic analysis}

Economic indices viz., the total cost of cultivation, gross return, net return and benefit cost ratio were worked out for various zinc fertilization treatments.

\section{RESULTS AND DISCUSSION}

\section{Effect of zinc fertilization on yield of babycorn}

In the present investigation, zinc fertilization had a significant effect on green cob yield and babycorn yield, as mentioned in Table 1. Soil application of zinc sulphate at $25 \mathrm{~kg} \mathrm{ha}^{-1}$ and $37.5 \mathrm{~kg} \mathrm{ha}^{-1}$ and foliar spray (@ $0.5 \%$ and $1.0 \%$ ) were statistically similar and increased the green cob yield to the tune of 19.5 per cent and 21.5 per cent, 24 per cent and 24.6 per cent, respectively as per the successive increment in zinc fertilization over control. An increasing trend in babycorn yield was also observed with increased zinc fertilization. The increased yield might be due to the beneficial effect of $\mathrm{Zn}$ in the plant system. Better utilization of zinc in plant resulted in higher leaf area, photosynthetic efficiency, total dry matter production and yield attribute that led to increased green cob and babycorn yield.

Application of zinc sulphate in soil @ $37.5 \mathrm{~kg} \mathrm{ha}^{-1}$ with foliar spray of $0.5 \%$ on 20 DAS and 40 DAS $\left(T_{8}\right)$ recorded the maximum green fodder yield (30492 kg ha ${ }^{-1}$ ) with an increment of 26 per cent over control. The favourable effect of $\mathrm{Zn}$ application on green fodder yield was attributed to the overall growth and development under a higher supply of zinc which enhanced the source to sink relationship and led to an increase in the green fodder yield.
The results are in accordance with the findings of Chand and Susheela (2017), who reported that the soil application of zinc sulphate @ $25 \mathrm{~kg} / \mathrm{ha}$ with foliar spray of zinc sulphate at $0.2 \%$ on 25 DAS and 40 DAS was found to produce higher yields viz., corn yield (1566 kg/ha), cob yield (6311 kg/ha), husk yield (4744 $\mathrm{kg} / \mathrm{ha})$ and green fodder yield (27.48 t/ha).

\section{Effect of zinc fertilization on quality parameters of babycorn}

Crude protein content was highly influenced by zinc fertilization (Table 2). Application of zinc sulphate @ $37.5 \mathrm{~kg} \mathrm{ha}^{-1}$ in soil and foliar spray of $0.5 \%$ on 20 and 40 DAS $\left(T_{8}\right)$ recorded higher crude protein $(9.83 \%)$ to a tune of $31.2 \%$ increase over control. However, the treatment was statistically on par with treatment $T_{9}$ and $\mathrm{T}_{7}$, which recorded the crude protein values of $9.25 \mathrm{per}$ cent and 9.22 per cent, respectively. The increase in the crude protein content of the cobs might be due to increased concentration of nitrogen through higher nitrogen uptake as reported by Sharma et al. (2012).

Total soluble sugar content was significantly affected by zinc fertilization treatments (Table 2). The TSS content ranged from 1.42 per cent to 1.65 per cent. Zinc sulphate application in soil @ $37.5 \mathrm{~kg} / \mathrm{ha}$ along with $0.5 \%$ foliar spray at 20 DAS and 40 DAS $\left(T_{8}\right)$ recorded a higher TSS of $1.65 \%$ and it was statistically on par with the treatments $T_{9}, T_{7}, T_{6}$ and $T_{5}$. The lowest TSS of $1.42 \%$ was recorded in control $\left(T_{1}\right)$. The increased total sugar content might be due to a better source-sink relationship, greater balanced absorption and translocation of nutrients to different plant parts resulting in higher values of sugars of babycorn under higher doses of zinc fertilization.

Zinc fertilization had significantly affected the starch content also (Table 2). In the present investigation, a higher value of starch content $(8.17 \%)$ was recorded with the application of zinc sulphate @ $37.5 \mathrm{~kg} \mathrm{ha}^{-1}$ in soil with foliar spray of $0.5 \%$ on 20 and 40 DAS $\left(T_{8}\right)$ over other treatments but it was statistically on par with

Table 1. Effect of zinc fertilization on yield of babycorn.

\begin{tabular}{|c|c|c|c|}
\hline Treatments & $\begin{array}{l}\text { Green cob } \\
\text { yield }\left(\mathrm{kg} \mathrm{ha}^{-1}\right)\end{array}$ & $\begin{array}{l}\text { Babycorn } \\
\left.\text { yield (kg ha }{ }^{-1}\right)\end{array}$ & $\begin{array}{l}\text { Green fodder } \\
\text { Yield }\left(\mathrm{kg} \mathrm{ha}^{-1}\right)\end{array}$ \\
\hline $\mathrm{T}_{1}:$ Control (No Zinc) & 14378 & 3658 & 24136 \\
\hline $\mathrm{T}_{2}: \mathrm{ZnSO}_{4} @ 25 \mathrm{~kg} \mathrm{ha}^{-1}$ as soil application & 16115 & 4375 & 25615 \\
\hline $\mathrm{T}_{3}: \mathrm{ZnSO}_{4} @ 37.5 \mathrm{~kg} \mathrm{ha}^{-1}$ as soil application & 16328 & 4369 & 26121 \\
\hline $\mathrm{T}_{4}$ : Foliar spray of $\mathrm{ZnSO}_{4} @ 0.5 \%$ on 20 and 40 DAS & 16425 & 4460 & 26385 \\
\hline $\mathrm{T}_{5}$ : Foliar spray of $\mathrm{ZnSO}_{4} @ 1.0 \%$ on 20 and 40 DAS & 16571 & 5338 & 26695 \\
\hline $\mathrm{T}_{6}: \mathrm{T}_{2}$ and $\mathrm{T}_{4}$ & 17189 & 5317 & 28160 \\
\hline $\mathrm{T}_{7}: \mathrm{T}_{2}$ and $\mathrm{T}_{5}$ & 17476 & 5578 & 28842 \\
\hline $\mathrm{T}_{8}: \mathrm{T}_{3}$ and $\mathrm{T}_{4}$ & 17837 & 5778 & 30492 \\
\hline$T_{9}: T_{3}$ and $T_{5}$ & 17916 & 5989 & 29706 \\
\hline Sed & 787 & 287 & 1162 \\
\hline$C D(P=0.05)$ & 1669 & 607 & 2463 \\
\hline
\end{tabular}


Amutham, G. T. et al. / J. Appl. \& Nat. Sci. 13 (SI), 80 - 85 (2021)

Table 2. Effect of zinc fertilization on quality parameters of babycorn.

\begin{tabular}{llcll}
\hline Treatments & $\begin{array}{l}\text { Crude } \\
\text { Protein (\%) }\end{array}$ & $\begin{array}{l}\text { Total sugar } \\
\text { content (\%) }\end{array}$ & $\begin{array}{l}\text { Starch } \\
\text { content (\%) }\end{array}$ & $\begin{array}{l}\text { Zinc content } \\
\text { (mg kg }\end{array}$ \\
\hline $\mathrm{T}_{1}:$ Control (No Zinc) & 7.49 & 1.42 & 6.83 & 32.6 \\
$\mathrm{~T}_{2}: \mathrm{ZnSO}_{4} @ 25 \mathrm{~kg} \mathrm{ha}^{-1}$ as soil application & 8.16 & 1.46 & 7.20 & 35.8 \\
$\mathrm{~T}_{3}: \mathrm{ZnSO}_{4} @ 37.5 \mathrm{~kg} \mathrm{ha}^{-1}$ as soil application & 7.94 & 1.48 & 7.28 & 37.9 \\
$\mathrm{~T}_{4}:$ Foliar spray of $\mathrm{ZnSO}_{4} @ 0.5 \%$ on 20 and 40 DAS & 7.75 & 1.49 & 7.32 & 39.4 \\
$\mathrm{~T}_{5}:$ Foliar spray of $\mathrm{ZnSO}_{4} @ 1.0 \%$ on 20 and 40 DAS & 9.06 & 1.52 & 7.38 & 39.7 \\
$\mathrm{~T}_{6}: \mathrm{T}_{2}$ and $\mathrm{T}_{4}$ & 8.61 & 1.56 & 7.61 & 41.2 \\
$\mathrm{~T}_{7}: \mathrm{T}_{2}$ and $\mathrm{T}_{5}$ & 9.22 & 1.60 & 7.72 & 42.5 \\
$\mathrm{~T}_{8}: \mathrm{T}_{3}$ and $\mathrm{T}_{4}$ & 9.83 & 1.65 & 8.17 & 43.9 \\
$\mathrm{~T}_{9}: \mathrm{T}_{3}$ and $\mathrm{T}_{5}$ & 9.25 & 1.63 & 8.12 & 43.4 \\
Sed & 0.52 & 0.06 & 0.35 & 1.7 \\
$\mathrm{CD}(\mathrm{P}=0.05)$ & 1.10 & 0.13 & 0.75 & 3.6 \\
\hline
\end{tabular}

Table 3. Effect of zinc fertilization on plant N, P, K and Zn uptake at different stages of babycorn.

\begin{tabular}{|c|c|c|c|c|c|c|c|c|c|c|c|c|}
\hline \multirow{2}{*}{ Treatments } & \multicolumn{3}{|c|}{$\begin{array}{l}\text { Total nitrogen } \\
\text { uptake }\left(\mathrm{kg} \mathrm{ha}^{-1}\right)\end{array}$} & \multicolumn{3}{|c|}{$\begin{array}{l}\text { Total phosphorus } \\
\text { uptake }\left(\mathrm{kg} \mathrm{ha}^{-1}\right)\end{array}$} & \multicolumn{3}{|c|}{$\begin{array}{l}\text { Total potassium } \\
\text { uptake }\left(\mathrm{kg} \mathrm{ha}^{-1}\right)\end{array}$} & \multicolumn{3}{|c|}{$\begin{array}{c}\text { Total zinc } \\
\text { uptake ( }\left(\mathrm{g} \mathrm{ha} \mathbf{a}^{-1}\right)\end{array}$} \\
\hline & $\begin{array}{l}25 \\
\text { DAS }\end{array}$ & $\begin{array}{l}45 \\
\text { DAS }\end{array}$ & Harvest & $\begin{array}{l}25 \\
\text { DAS }\end{array}$ & $\begin{array}{l}45 \\
\text { DAS }\end{array}$ & $\begin{array}{l}\text { Har- } \\
\text { vest }\end{array}$ & $\begin{array}{l}25 \\
\text { DAS }\end{array}$ & $\begin{array}{l}45 \\
\text { DAS }\end{array}$ & $\begin{array}{l}\text { Har- } \\
\text { vest }\end{array}$ & $\begin{array}{l}25 \\
\text { DAS }\end{array}$ & $\begin{array}{l}45 \\
\text { DAS }\end{array}$ & $\begin{array}{l}\text { Har- } \\
\text { vest }\end{array}$ \\
\hline $\mathrm{T}_{1}$ & 17.8 & 95.7 & 124.1 & 1.3 & 14.5 & 22.5 & 6.6 & 66.3 & 95.1 & 35.4 & 209.5 & 286.8 \\
\hline $\mathrm{T}_{2}$ & 18.5 & 101.7 & 162.2 & 1.1 & 12.6 & 22.1 & 7.1 & 73.6 & 111.7 & 41.9 & 260.1 & 335.3 \\
\hline $\mathrm{T}_{3}$ & 20.2 & 117.5 & 167.6 & 1.2 & 13.5 & 21.0 & 7.3 & 86.6 & 111.5 & 42.7 & 234.9 & 385.8 \\
\hline $\mathrm{T}_{4}$ & 21.0 & 130.1 & 176.2 & 1.2 & 13.6 & 21.8 & 7.7 & 99.6 & 121.9 & 57.0 & 240.4 & 422.8 \\
\hline $\mathrm{T}_{5}$ & 21.7 & 129.2 & 180.4 & 1.1 & 13.9 & 21.5 & 7.8 & 94.2 & 129.6 & 54.9 & 320.5 & 439.0 \\
\hline $\mathrm{T}_{6}$ & 22.3 & 131.3 & 187.3 & 1.2 & 13.8 & 22.1 & 7.8 & 94.4 & 141.4 & 58.5 & 370.0 & 504.0 \\
\hline $\mathrm{T}_{7}$ & 23.2 & 137.9 & 192.9 & 1.2 & 12.3 & 21.3 & 8.8 & 107.8 & 151.0 & 58.7 & 384.6 & 507.1 \\
\hline $\mathrm{T}_{8}$ & 24.0 & 147.4 & 207.3 & 1.1 & 12.5 & 21.6 & 9.4 & 115.0 & 158.0 & 63.5 & 430.0 & 544.5 \\
\hline $\mathrm{T}_{9}$ & 24.0 & 141.4 & 195.1 & 1.1 & 12.6 & 21.4 & 9.3 & 114.8 & 158.3 & 63.6 & 428.6 & 567.3 \\
\hline Sed & 1.3 & 8.1 & 11.3 & 0.1 & 1.0 & 1.3 & 0.5 & 6.2 & 7.2 & 3.0 & 10.2 & 32.0 \\
\hline $\begin{array}{l}C D \\
(P=0.05)\end{array}$ & 2.6 & 17.2 & 24.0 & NS & NS & NS & 1.0 & 13.1 & 15.3 & 6.4 & 21.7 & 67.8 \\
\hline
\end{tabular}

$T_{9}, T_{7}$ and $T_{6}$ treatments. The reason might be due to the large availability of the micronutrient in soil solution and its uptake by the crop. Kumar and Bohra (2014) reported that starch contents in babycorn were significantly affected by zinc at $5 \mathrm{~kg} / \mathrm{ha}$.

The data of zinc content in corn (Table 2) in the present study revealed that higher accumulation of zinc was recorded $(43.9 \mathrm{ppm})$ in the application of zinc sulphate in soil @ $37.5 \mathrm{~kg} \mathrm{ha}^{-1}$ with foliar spray of $0.5 \%$ at 20 and 40 DAS $\left(\mathrm{T}_{8}\right)$. It was followed by zinc sulphate application in soil @ $37.5 \mathrm{~kg} \mathrm{ha}^{-1}$ with foliar spray of $1.0 \%$ at 20 and 40 DAS $\left(T_{9}\right)$. The increase in $\mathrm{Zn}$ content in corn might be due to the presence of higher amount of zinc in soil solution by the application of $\mathrm{ZnSO}_{4}$ and due to its moderate phloem mobility, it's might have favourable absorption by babycorn crop and translocated in the grains during the maturity phase as also observed by Arabhanvi and Hulihalli (2018).
Effect of zinc fertilization on nutrients uptake of babycorn

Among the different levels of application of zinc sulphate tested, combined application of zinc sulphate of $37.5 \mathrm{~kg} \mathrm{ha}^{-1}$ in soil with foliar spray of $0.5 \%$ on 20 and 40 DAS $\left(\mathrm{T}_{8}\right)$ recorded a profound influence on $N$ uptake during respective growth stages (Table 3 ). This might be due to the synergistic effect of $\mathrm{Zn}$ on $\mathrm{N}$ and also due to better foraging capacity of roots led to better growth and development.

The $P$ uptake had not been significantly influenced by zinc fertilization at all growth stages. The reason might be that increased zinc uptake depressed the root phosphorus uptake and translocation from root to shoot.

The $\mathrm{K}$ uptake had been significantly influenced by zinc fertilization at all growth stages. Application of zinc 
Table 4. Economics of babycorn as influenced by zinc fertilization.

\begin{tabular}{|c|c|c|c|c|}
\hline Treatments & $\begin{array}{l}\text { Total cost of } \\
\text { cultivation } \\
\left(\text { ₹ ha }^{-1}\right)\end{array}$ & $\begin{array}{l}\text { Gross } \\
\text { return } \\
\left(\text { ₹ha }^{-1}\right)\end{array}$ & $\begin{array}{l}\text { Net } \\
\text { return } \\
\left(\text { ₹ha }^{-1}\right)\end{array}$ & $\begin{array}{l}\text { B:C } \\
\text { Ratio }\end{array}$ \\
\hline $\mathrm{T}_{1}:$ Control (No Zinc) & 75667 & 335832 & 260165 & 4.44 \\
\hline $\mathrm{T}_{2}: \mathrm{ZnSO}_{4} @ 25 \mathrm{~kg} \mathrm{ha}^{-1}$ as soil application & 77217 & 373530 & 296313 & 4.84 \\
\hline $\mathrm{T}_{3}: \mathrm{ZnSO}_{4} @ 37.5 \mathrm{~kg} \mathrm{ha}^{-1}$ as soil application & 77992 & 378802 & 300810 & 4.86 \\
\hline $\mathrm{T}_{4}$ : Foliar spray of $\mathrm{ZnSO}_{4} @ 0.5 \%$ on 20 and 40 DAS & 75977 & 381270 & 305293 & 5.02 \\
\hline $\mathrm{T}_{5}$ : Foliar spray of $\mathrm{ZnSO}_{4} @ 1.0 \%$ on 20 and 40 DAS & 76287 & 384810 & 308523 & 5.04 \\
\hline $\mathrm{T}_{6}: \mathrm{T}_{2}$ and $\mathrm{T}_{4}$ & 77527 & 400100 & 322573 & 5.16 \\
\hline $\mathrm{T}_{7}: \mathrm{T}_{2}$ and $\mathrm{T}_{5}$ & 77837 & 407204 & 329367 & 5.23 \\
\hline $\mathrm{T}_{8}: \mathrm{T}_{3}$ and $\mathrm{T}_{4}$ & 78302 & 417724 & 339422 & 5.33 \\
\hline $\mathrm{T}_{9}: \mathrm{T}_{3}$ and $\mathrm{T}_{5}$ & 78612 & 417732 & 339120 & 5.31 \\
\hline
\end{tabular}

sulphate @37.5 kg ha ${ }^{-1}$ with foliar spray of either $0.5 \%$ or $1.0 \%$ at 20 and 40 DAS $\left(\mathrm{T}_{8}\right)$ recorded higher $\mathrm{K}$ uptake during respective growth stages (Table 3 ). Higher availability of $\mathrm{K}$ was observed and it's might be due to synergistic effect between $\mathrm{Zn}$ and $\mathrm{K}$. The results conform with the finding of Muthumanickam et al. (2015), who opined that the combined application of $\mathrm{K} @ 75$ kg with Zn@ @.5kg/ha and B @ 1.0 kg/ha had a significant increase in maximum $\mathrm{Zn}, \mathrm{B}$ and $\mathrm{K}$ uptake in maize grain.

Zinc fertilization had significantly influenced the zinc uptake in babycorn. Application of zinc sulphate in soil @ $37.5 \mathrm{~kg} \mathrm{ha}^{-1}$ with foliar spray of either $0.5 \%$ or $1.0 \%$ at 20 and 40 DAS $\left(T_{8}\right)$ recorded higher $\mathrm{Zn}$ uptake during the respective growth stages (Table 3 ). This might be due to external application of zinc through soil and foliar application of $z \mathrm{n}$. This zinc concentration in the plants which may resulted in better translocation of the nutrient from source to sink.

\section{Economics}

The economics of babycorn as influenced by zinc fertilization in the present study (Table 4) revealed that application of zinc sulphate in soil @ $37.5 \mathrm{~kg} \mathrm{ha}^{-1}$ with foliar spray @ $1.0 \%$ at 20 and 40 DAS ( $\left.\mathrm{T}_{9}\right)$ incurred higher cost of cultivation (78612 ₹ha ${ }^{-1}$ ) and attained higher gross return (417732 ₹ha-1) and benefit cost ratio of 5.31. Maximum net return (339422 ₹ha $^{-1}$ ) and benefit cost ratio of 5.33 was attained with application of zinc sulphate in soil @ $37.5 \mathrm{~kg} \mathrm{ha}^{-1}$ with foliar spray @ $0.5 \%$ at 20 and 40 DAS $\left(T_{8}\right)$. This was attributed to the production of higher green cob and green fodder yields over other treatments. It is obvious because of the favourable effect of zinc application in the production of higher babycorn and green fodder yields. The results of Palai et al. (2018) found that there was highest net return (₹165442 / ha) with soil application of Zn @ 6 kg $\mathrm{ha}^{-1}+$ foliar spray @ 0.05\% Zn at 25 DAS with seed treatment @ $0.6 \% \mathrm{Zn}$. The B: C ratio was also highest (4.46) in soil application of Zn @ $6 \mathrm{~kg} \mathrm{ha}^{-1}+$ foliar spray @ $0.05 \% \mathrm{Zn}$ at 25 DAS.

\section{Conclusion}

Increased yield attributes such as the number of cobs/ plant, cob and corn length, cob and corn weight, cob and corn girth were observed with combined application of $\mathrm{ZnSO}_{4} @ 37.5 \mathrm{~kg} / \mathrm{ha}$ in soil with foliar spray @ $0.5 \%$ at 20 and 40 DAS. Quality parameters of babycorn like crude protein, total soluble sugars, starch and $\mathrm{Zn}$ content in corn were significantly influenced soil application of $\mathrm{ZnSO}_{4} @ 37.5 \mathrm{~kg} / \mathrm{ha}$ with foliar spray of $0.5 \%$ at 20 and 40 DAS recorded higher values of these quality characters. Plant nutrient uptake of $\mathrm{N}, \mathrm{K}$ and $\mathrm{Zn}$ by the babycorn crop was significantly influenced by the application of $\mathrm{ZnSO}_{4} @ 37.5 \mathrm{~kg} / \mathrm{ha}$ in soil with foliar spray of $0.5 \%$ at 20 and 40 DAS. Higher net monetary return and $\mathrm{B}$ : $\mathrm{C}$ ratio were obtained with application of $\mathrm{ZnSO}_{4}$ at $37.5 \mathrm{~kg} / \mathrm{ha}$ in soil with foliar spray @ $0.5 \%$ on 20 DAS and 40 DAS followed by application of $\mathrm{ZnSO}_{4}$ at $37.5 \mathrm{~kg} / \mathrm{ha}$ in soil with foliar spray @ $1.0 \%$ on 20 DAS and 40 DAS. From the present study, it could be concluded that applying zinc sulphate to soil @37.5 kg ha ${ }^{-1}$ with foliar spray @ $0.5 \%$ at 20 and 40 DAS could be a successful practice for achieving higher productivity, profitability with bio-fortification of $\mathrm{Zn}$ in babycorn under irrigated condition.

\section{Conflict of interest}

The authors declare that they have no conflict of interest.

\section{REFERENCES}

1. Arabhanvi, F. \& Hulihalli U.K. (2018). Agronomic fortification with zinc and iron to enhancing micronutrient concentration in sweet corn grain to ameliorate the deficiency 
symptoms in human beings. International Journal of Current Microbiology and Applied Sciences, 7 (2), 333-340.

2. Bagci, S.A., Ekiz, H., Yilmaz, A. \& Cakmak, I. (2007). Effects of zinc deficiency and drought on grain yield of field-grown wheat cultivars in Central Anatolia. Journal of Agronomy and Crop Science,193 (3),198-206.

3. Caballero, B. (2002). Global patterns of child health: the role of nutrition. Annals of Nutrition and Metabolism, 46 (Suppl. 1), 3-7.

4. Chand, S.W. \& Susheela, R. (2017). Effect of zinc fertilization on growth, yield and quality of baby corn (zea mays I.). M.Sc. Thesis. Department of Agronomy, Professor Jayashankar Telangana State Agricultural University.

5. Dubetz, S. \& Wells, S.A. (1968). Reaction of barley varieties to nitrogen fertilizer. The Journal of Agricultural Science, 70 (3), 253-256.

6. Graham, R.D. \& Welch, R.M. (2008). Micronutrient deficiencies in crops and their global significance. In : Micronutrient deficiencies in global crop production, 41-61. Springer.

7. Hedge, J.E. \& Hofreiter, B.T. (1962). In carbohydrate chemistry 17 (Eds whistler RL and Be Millee, JN) Academic press. New York, 17.

8. Hershfinkel, M., Silverman, W.F. \& Sekler, I. (2007). The zinc sensing receptor, a link between zinc and cell signaling. Molecular Medicine, 13(7), 331-336.

9. Humphries, E.C. (1956). Mineral components \& ash analysis. In Moderne Methoden der Pflanzenanalyse/Modern Methods of Plant Analysis, 468-502. Springer.

10. Jackson, M.L. (1973). Soil Chemical Analysis. Prentice Hall of India Private Limited. New Delhi,498

11. Kawatra, A. \& Sehgal, S. (2007). Value added products of maize. Report of the national conference on doubling maize production, New Delhi.
12. Kumar, R. \& Bohra, J.S. (2014). Effect of NPKS and Zn application on growth, yield, economics and quality of baby corn. Archives of Agronomy and Soil Science, 60 (9), 1193-1206.

13. Meena, S.K., Mundra, S.L. \& Singh, P. (2013). Response of maize (Zea mays) to nitrogen and zinc fertilization. Indian Journal of Agronomy, 58(1), 127-128.

14. Muthumanickam, D., Stalin, P. \& shukla, A.K. (2015). Enhancing use efficiency and crop productivity of maize through $\mathrm{Zn}$ and $\mathrm{B}$ application. Proceedings of the National Seminar on soil resilience-2015, Madurai.

15. Peck, A.W. \& Mcdonald, G.K. (2010). Adequate zinc nutrition alleviates the adverse effects of heat stress in bread wheat. Plant and Soil, 337 (1-2), 355-374.

16. Sharma, S., Gupta, J.P., Nagi, H.P.S. \& Kumar, R. (2012). Effect of incorporation of corn byproducts on quality of baked and extruded products from wheat flour and semolina. Journal of Food Science and Technology, 49 (5), 580586.

17. Thavaprakaash, N., Velayudham, K. \& Muthukumar, V.B. (2005). Effect of crop geometry, intercropping systems and integrated nutrient management practices on productivity of baby corn (Zea mays L.) based intercropping systems. Research Journal of Agricultural and Biological Sciences, 1 (4), 295-302.

18. Yemm, E.W. \& Willis, A.J. (1954). The estimation of carbohydrates in plant extracts by anthrone. Biochemical Journal, 57 (3), 508.

19. Yodpet, C. (1979). Studies on sweet corn as potential young cob corn (Zea mays, L). University of the Philippines, Los Banos. 